\title{
PAUL, ESCHATOLOGY AND THE AUGUSTAN AGE OF GRACE
}

\author{
J.R. Harrison
}

\begin{abstract}
Summary
This article proposes that Paul worked on two cultural fronts in describing the reign of grace (Rom. 5:12-21) and the new creation (Rom. 8:18-39). Paul's references to the 'two ages', the fall of Adam and the new creation, were fundamental to Jewish apocalyptic eschatology. However, Paul's language of grace in Romans 5, with its emphasis on excess and abundance, would have evoked imperial associations. In the first century, the eschatological age of Augustus marked a watershed in beneficence. Paul's point to the Roman Christians was plain: Christ's grace surpassed the very best the Caesars had to offer.
\end{abstract}

\section{Introduction}

When Paul describes the reign of grace in Romans 5:12-21, his description has significance in relation to both distinctively Jewish and Graeco-Roman contexts of thought, drawing upon the rich eschatological traditions of both in his portrait of divine beneficence. However, New Testament scholars have traditionally viewed Romans 5:12-21 and 8:18-39 solely from the perspective of Jewish apocalyptic eschatology. Not surprisingly, the 'two ages', the fall of Adam, and the new creation have dominated the discussion. As a result, the imperial associations evoked by Paul's language of grace have been overlooked. A theological tunnel vision has obscured the fact that Paul was writing to Romans who lived in the city of Augustus, the cosmic Saviour-Benefactor. I will seek to demonstrate that the Augustan age of grace was the touchstone for first-century Roman readers who wanted to assess the scope of Christ's reign of grace. It is my contention that the echoes of Augustan benefaction propaganda in Romans represent an intentional rhetorical strategy on the apostle's part rather than an unconscious appropriation of familiar motifs. 
My approach is indebted to the pioneering work of D. Georgi on Roman imperial eschatology and its relation to the New Testament documents. ${ }^{1}$ According to Georgi, Paul's theology has a decidedly political edge. When Paul proclaimed Jesus as Saviour and Lord, he challenged the imperial ideology of power that shaped social relations between the Roman elite and their dependants in the first century AD. Several scholars have followed Georgi's lead. B. Witherington III has incorporated aspects of Georgi's approach in discussing Roman Corinth; R.A. Horsley has edited a helpful collection of essays on Paul's stance towards the Roman empire; and S.K. Stowers has interpreted Romans against the backdrop of the ethics of self-mastery, a prominent feature of Augustus' social revolution. ${ }^{2}$

The time is opportune for an investigation of Paul's language of grace against the background of the eschatological claims made about

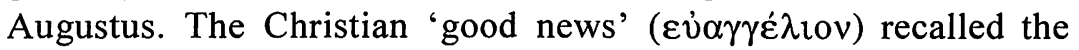
memory of an earlier saviour: a lavish Roman benefactor who, as the culmination of Providence, had so emptied himself of grace that 'in private life (he) was poor, in public life rich'. ${ }^{3}$

At the outset, I will focus on how Paul interacts with Jewish apocalyptic eschatology in his portrayal of the new age of Christ. How did Paul speak to the eschatological hopes of the Jewish believers living at Rome? I will then concentrate on Augustan benefaction propaganda and how its contours fit into Paul's theological landscape. How did Paul capture the interest of Roman Gentile believers who were the heirs of the Augustan age of grace?

\section{Paul, Jewish eschatology and the reign of grace}

The Jewish eschatology underlying the Adam-Christ typology in Romans 5:12-21 is well known. For example, in regard to Romans $5: 15 \mathrm{~b}, \mathrm{M}$. Theobald has argued that Paul employs apocalyptic and rabbinic traditions (4 Ezra 4:29-30; 8:31-36; Sipre Lev. 5:17

I D. Georgi, 'Who is the True Prophet?', HTR 79 (1986) 100-26; idem, Theocracy in Paul's Praxis and Theology (Minneapolis: Fortress, 1991).

2 B. Witherington III, Conflict and Community in Corinth: A Socio-Rhetorical Commentary on 1 and 2 Corinthians (Grand Rapids: Eerdmans, 1995) 295-98; R.A. Horsley (ed.), Paul and Empire: Religion and Power in Roman Imperial Society (Harrisburg: Trinity Press International, 1997); S.K. Stowers, A Rereading of Romans: Justice, Jews and Gentiles (New Haven and London: Yale University Press, 1994) 42-82.

3 Dio, Roman History 56.41 .5 (cf. 2 Cor. 8:9). 
[120a]) - in conjunction with the verb 'to abound' ( $\pi \varepsilon \rho ı \sigma \sigma \varepsilon v i \varepsilon ı)$ - to underscore the eschatological fullness of God's grace. ${ }^{4}$ New Testament scholars have also drawn attention to the fact that Paul employs several familiar Jewish eschatological motifs to illustrate the 'reign of grace' in Romans 5:12-21, as well the new creation in Romans 8:18-25. Three features stand out.

First, when Paul speaks of 'grace', 'death' and 'sin' as reigning powers $(\beta \alpha \sigma i \lambda \varepsilon v i \varepsilon v v ; 5: 14,17,21)$, he alludes to the familiar idea of dominions ('ages') in Jewish eschatological tradition. ${ }^{5}$ Thus the new age of grace and its gift of righteousness (Rom. 5:17b, 21b) has supplanted the present age of sin and death $(5: 14 a, 17 a, 21 a)$. The eschatological newness of grace is underscored by the accompanying language of abundance $(5: 15,17,20$; cf. $6: 20 ; 2$ Cor. $4: 15 ; 8: 7 ; 9: 8$; Eph. 1:7-8; 1 Tim. 1:14) and by the contrasts of death and life $(5: 12$, $14,17,21)$.

In the case of Jewish apocalyptic eschatology, 4 Ezra asserts that 'the Most High has made not one age but two'. 6 The 'age to come' will supplant the present age which, according to 4 Ezra, 'is full of sadness and infirmities'. ${ }^{7}$ Paul is entirely conversant with this view. He refers to 'this age' seven times in the Roman and Corinthian epistles (Rom. 12:12; 1 Cor. 1:20; 2:6 [twice], 8; 3:18; 2 Cor. 4:4), while in Galatians 1:4 he speaks of 'the present evil age'. If we accept Ephesians as a genuine Pauline epistle, Paul distinguishes between 'the present age' and the 'age to come' (Eph. 1:21).

But Paul transforms the Jewish apocalyptic tradition of the 'two ages'. Instead of postponing the advent of the 'age to come', as Jewish apocalyptic writers usually did, Paul asserts that the new age of Christ had broken into the present evil age and that its reality was

4 M. Theobald, Die überströmende Gnade: Studien zu einem paulinischen Motivfeld (Würzburg: Echter Verlag, 1982) 94-96. Note the comment of K. Berger (' $\chi \alpha$ ó $\varsigma^{\prime}$, H. Balz and G. Schneider [ed.], Exegetical Dictionary of the New Testament Vol. 3 [Grand Rapids: Eerdmans, 1993] 459): 'Romans 5 relates the messianic category of superabundance to the apocalyptic vision of the increase of evil: the overabundance of evil is reversed and simultaneously eclipsed by increased fullness.'

5 D. Moo, The Epistle to the Romans (Grand Rapids: Eerdmans, 1996) 349. A. Nygren (Commentary on Romans [Philadelphia: Fortress, 1949] 20) claims that the 'two aeons' contrast of Rom. 5:12-21 is the 'high point of the epistle, in the light of which the whole is best to be understood'; see also P. Achtemeier, Romans (Louisville: John Knox, 1985) 4-18. Although this exaggerates the pervasiveness of the 'two ages' doctrine in Romans, Nygren is correct in pointing to the centrality of eschatological motifs in Paul's theology.

64 Ezra 7:50. See also 4 Ezra 4:2; 6:9; 7:13, 122-23; 8:1; 9:19.

74 Ezra 4:27. 
currently the experience of the church. ${ }^{8}$ As he observes in 1 Corinthians 10:11, believers are those upon whom 'the fulfilment of the ages has come'.

Second, several Jewish apocalyptic works comment on the relationship between universal death and the sin of Adam. ${ }^{9} 4$ Ezra and 2 Baruch graphically portray the effects that Adam's transgression of the commandment had on his descendants. ${ }^{10}$ The descendants are cut off from the glory of God, are ungodly and disobedient, and face the prospect of death and the eternal fire. Even the provision of God's holy law could not counteract the debilitating effects of their 'evil hearts'. ${ }^{11}$ Paul's emphasis upon the corporate dimension of Adam's disobedience in Romans 5:12-21 and the ineffectiveness of the law (Rom. 3:20; 4:15; 5:20; 7:5, 7-13; cf. Gal. 3:23-24) is consonant with this analysis of the human predicament. ${ }^{12}$

Third, in Romans 8:19 Paul states that the creation 'waits in eager expectation for the sons of God to be revealed'. Given that, in Old Testament traditions, the renewal of God's people was to be accomplished by a cosmic renewal (e.g. Is. 65:17, 25;66:22), ${ }^{13}$ it is likely that Paul reflects Jewish eschatological traditions when he claims that the created order would be liberated from its bondage to the powers of evil (Rom. 8:18-25). Thus 4 Ezra speaks of the suffering brought about by Adam's fall and the prospect of the glory to come:

And so the entrances of this world were made narrow and sorrowful and toilsome; they are few and evil, full of dangers and involved in great hardships. But the entrances of the greater world are broad and safe, and

8 Rom. 6:4b; 7:6b; 1 Cor. 1:18-29; 2 Cor. 3:6-11; 5:17; Gal. 1:4; 4:4-6; 6:15.

9 For discussion, see A.J.M. Wedderburn, 'The Theological Structure of Romans V.12', NTS 19 (1972-73) 332-54, esp. 340-41.

10 Ezra 3:4-11, 20-26; 4:26-32; 2 Bar. 17:1-3; cf. also 3 Bar. 4:16.

114 Ezra $3: 20-26 ; 4: 26-32 ; 7: 45-51$. On the 'evil heart' and Adam's sin in 4 Ezra, see M.E. Stone, Fourth Ezra (Minneapolis: Fortress, 1990) 63-67.

12 Paul's critique of the law is more radical than that of Jewish apocalyptic literature. According to Paul, the law is recruited against its will by the reigning and enslaving powers-Sin, Flesh and Death-which are ranged against humanity. Sin is aroused and empowered by the law (Rom. 7:5, 7-11, 13; 1 Cor. 15:56b). Although the law is holy and just and good (Rom. 7:7, 12-14, 16, 22), it is impotent to effect righteousness due to the sinful flesh (Rom. 8:3; cf. Gal. 3:2122). As a result, the law effects a ministry of death (Rom. 7:11b; 2 Cor. 3:7), calling down the divine wrath on humanity (Rom. 4:15; Gal. 3:10, 13; Col. 2:14) and causing the creation to long for the liberty of the eschatological age (Rom. 8:19-23). Only the reign of divine grace will bring delivery from its curse.

13 On the new creation, see D.S. Russell, The Method and Message of Jewish Apocalyptic (London: SCM, 1974) 280-84; D.E. Gowan, Eschatology in the Old Testament (Edinburgh: T \& T Clark, 1986) 113-18. 
yield the fruit of immortality. Therefore unless the living pass through the difficult and futile experiences, they can never receive those things that have been reserved for them. ${ }^{14}$

Elsewhere Paul modifies this view, preferring to speak of the presence of the new creation (2 Cor. 5:17; Gal. 6:15), rather than its future advent. The world, with its culture of sin and death, is passing away (1 Cor. 7:31) and the believer has been crucified to the world (Gal. $6: 14)$.

In sum, Romans 5:12-21 and 8:18-39 employ several familiar Jewish apocalyptic motifs. What would have surprised Paul's Jewish audience are the modifications that he made to the framework of this worldview. For Paul, the new age of grace and the new creation had already begun and were currently experienced in the body of Christ.

But did Paul have anything to say to the eschatological hopes of the Gentile believers living in the Graeco-Roman context of the imperial city of Rome?

\section{Paul, Roman eschatology and the reign of grace}

New Testament exegetes have been strangely reluctant to situate the reign of grace described in Romans 5:12-21 as much in the Roman eschatology of the Augustan era as in the eschatological traditions of Jewish literature. ${ }^{15}$ However, Georgi has noted that 'the gospel according to Augustus had the world spellbound', ${ }^{16}$ including (presumably) some of the Roman Christians to whom Paul later wrote. From the late first century BC, as the Julian house eclipsed its rivals, beneficence was monopolised by the Caesars. The onesidedness of this contest struck contemporary observers as a turningpoint in Roman history and this was reflected in the Augustan propaganda.

144 Ezra 7:10-14. According to J.J. Collins (The Apocalyptic Imagination [New York: Crossroad, 1984] 162), this passage is the point wherein the author's focus 'shifts from the specific destiny of Israel to the more general problem of human inability to satisfy the law'. See further B.W. Longenecker, Eschatology and the Covenant: A Comparison of 4 Ezra and Romans 1-11 (JSNTS 57: Sheffield: Sheffield Academic Press, 1991); idem, 2 Esdras (Sheffield: Sheffield Academic Press, 1995) 33-58.

15 See, however, F.W. Danker, Benefactor: Epigraphic Study of a Graeco-Roman and New Testament Semantic Field (St. Louis: Clayton Publishing House, 1982) 347. Note the eschatological motifs used by Statius (Silv. 4:1-3) of Domitian and (more controversially) by the Einsiedeln Eclogues of Nero.

16 Georgi, 'Prophet', 104. 
It is worth considering whether Paul's Roman auditors may have interpreted the reign of Christ's beneficence (Rom. 5:21: $\dot{\eta} \chi \alpha$ óp $\varsigma$ $\beta \alpha \sigma \imath \lambda \varepsilon v \sigma_{\eta} ;$ cf. 5:17b: $\left.\beta \alpha \sigma \imath \lambda \varepsilon v \sigma o v \sigma \imath v\right)$ against its Augustan counterpart. ${ }^{17}$ To be sure, it would be injudicious to press for an exclusively Caesarian reference when trying to explain the origin of Paul's regnal imagery in Romans 5:21. ${ }^{18}$ Nonetheless, the enormity of Augustus' beneficence was readily apparent to his contemporaries and successors. A letter of the Roman proconsul to the Asian League (9 BC) admits that 'it is difficult to return for (Augustus') many great

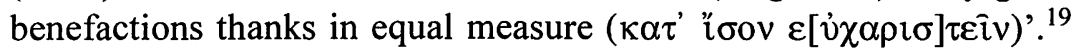
In his letter to the city of Gytheion (AD 15), the emperor Tiberius referred to 'the great size of the benefits of my father to all the world' ${ }^{20}$ In similar vein, Germanicus would later describe Augustus as 'the true saviour and the benefactor of the entire race of men'. ${ }^{21}$

More importantly, an overpowering sense of eschatological destiny had gripped the minds of the contemporaries of Augustus when they honoured the princeps. For example, the first decree of the Asian League concerning the new provincial calendar (Priene: $9 \mathrm{BC}$ ) is full of effusive praise as it recounts the merits of Augustus:

17 See the insightful comparison of Christ and Augustus in E. Stauffer, Christ and the Caesars: Historical Sketches (London: SCM, 1955) 90-111.

18 An overt allusion to Caesarian beneficence in Rom. 5:21 is (probably) ruled out when it is remembered that Augustus and his beneficiaries avoided regnal imagery in describing the principate. Since the Romans had ousted the monarchy and the Caesars emphasised their superiority to both client-kings and the monarchs of enemy nations (e.g. Augustus: Res Gestae 4, 27, 31-33; Caligula: R.K. Sherk, The Roman Empire: Augustus to Hadrian [Cambridge: CUP, 1988] §42B), this is perfectly understandable.

Further, Paul's imagery could equally be alluding to the beneficence of eastern potentates or of the Herods of Palestine. Significantly, in this regard, Antiochus 1 of Kommagene refers to his 'royal grace' $(\beta \alpha[\sigma \imath] \lambda \iota \kappa \alpha \hat{\imath} \varsigma \chi \alpha \dot{\alpha} \rho \iota \iota v$; Danker, Benefactor, $\$ 42 \mathrm{ll}$. 67-68). We must not also discount the possibility that Paul chose $\beta \alpha \sigma i \lambda \varepsilon v i \varepsilon i v$ because it evoked the Old Testament portrayal of God as king (e.g. 1 Sa. 8:7; Is. 6:5; Ps. 24:7; Je. 51:57; etc.).

19 V. Ehrenberg and A.H.M. Jones, Documents Illustrating the Reigns of Augustus and Tiberius (London: OUP, 1954) §98a (ll. 15-17). The first decree of the Asian League (Priene: $9 \mathrm{BC}$ ) asserts that the officials of Augustus had 'bestowed benefits on the province, the size of which benefits no speech would be adequate to relate' (ibid., 98b ll. 46-47). B.W. Winter (Seek the Welfare of the City: Christians as Benefactors and Citizens [Grand Rapids: Eerdmans, 1994] 125) cites a fragment from Nicolaus of Damascus (F.Gr. $90 \mathrm{~F} 125.1)$, the court historian of Herod the Great and a contemporary observer of Augustus. He spoke of the eagerness of cities to revere Augustus with temples and cultic worship due to 'the greatness of his virtue and the scale of his benefactions to them'. See also Philo, Leg. 147.

20 Sherk, The Roman Empire, §31.

21 Sherk, The Roman Empire, §42B (AD 18-19). 
[S]ince Providence, which has divinely disposed our lives, having employed zeal and ardour, has arranged the most perfect (culmination) for life ( $\tau$ ò $\left.\tau \varepsilon \lambda \eta{ }^{\prime} \tau \alpha \tau \nu \tau \hat{\omega} \beta i \omega\right)$ by producing Augustus, whom for the benefit of mankind (

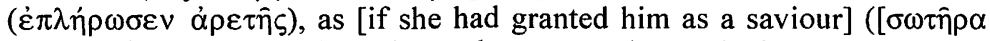
$\chi \alpha \rho i \sigma \alpha \mu \varepsilon \dot{\varepsilon} v]$ ) for us and our descendants, (a saviour) who brought war to an

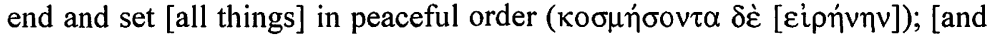

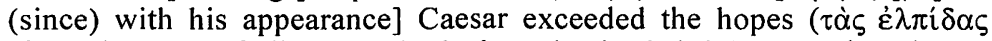

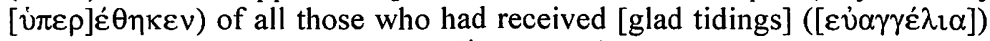
before us, not only surpassing ([ن $\pi \varepsilon \rho \beta \alpha] \lambda$ ó $\mu \varepsilon v o \varsigma)$ those who had been [benefactors] before him, but not even [leaving any] hope [of surpassing him] ( $\left.\dot{\varepsilon} \lambda \pi^{i} \delta[\alpha] \dot{v} \pi \varepsilon \rho \beta 0 \lambda \hat{\eta} \varsigma\right)$ for those who are to come in the future; and (since) the beginning of glad tidings ( $\varepsilon \dot{v} \alpha \gamma \gamma \varepsilon \lambda i[\omega v])$ on his account for the world was [the birthday] of the god...22

Further, the beneficent reign of Augustus is given quasi-cosmological significance by the Roman proconsul in his letter to the Asian League (Priene: 9 BC):

It is subject to question whether the birthday of our most divine Caesar spells more of joy or blessing, this being a date that we could probably without fear of contradiction equate with the beginning of all things $(\tau \hat{\eta} \tau \hat{\omega} \mathrm{v}$ $\pi \alpha \dot{\alpha} \tau \omega \nu \dot{\alpha} \rho \chi \hat{\eta})$, if not in terms of nature, certainly in terms of utility, seeing that he restored stability, when everything was collapsing and falling into disarray, and gave a new look to the entire world that would have been most happy to accept its own ruin had not the good and common fortune of all been born: Caesar. Therefore people might justly assume that his birthday

22 Ehrenberg and Jones, Documents, $\S 98 \mathrm{~b}$ (ll. 32-41). For its relevance to Rom. 5:12-13 and 8:18-19, note the comment of J. Rouffiac (Caractères du Grec, 72ff., cited by C. Spicq, Theological Lexicon of the New Testament Vol. 3 [Peabody, Mass.: Hendrickson, 1994] 353-54, n. 44) regarding the Priene inscription of Augustus: 'It probably would not have required much touching up of this text for a Christian to be able to apply it to Christ fifty years later. A saviour who realised ancestral hopes; who has a unique importance for humanity; who is so great that he will be never surpassed; whose birth marks the beginning of a new era: so many descriptions that one might think were created by Christian piety, but which nevertheless are found in a pagan inscription from not long before the birth of Jesus.'

$B M I 894$ (Halicarnassus: 2 BC [ll. 8-12]) combines realised and future eschatological elements in addressing Augustus as $\sigma \omega \tau \eta \dot{\eta} \rho$ : 'there is peace

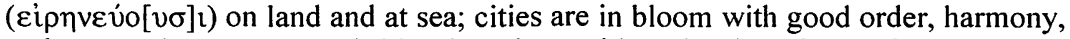
and prosperity; every good thing is at its zenith and point of maturity; there is a culmination of auspicious hopes ( $\dot{\varepsilon} \lambda \pi i \delta \omega \nu \chi \rho \eta \sigma \tau \hat{\omega} v)$ for the future, and there is the present cheerfulness of men who have been filled'. The same inscription states that Nature freely gave ( $\dot{\varepsilon} \chi \alpha i \sigma \alpha \tau)$ to humankind the greatest good in the form of Augustus' immeasurable beneficence ( $\varepsilon \dot{\varepsilon} \rho \gamma \varepsilon \sigma i \alpha \varsigma)$. In short, 'Providence not only made full (غ่ $\pi \lambda \dot{n} \rho \omega \sigma \varepsilon)$ the prayers of all but also transcended [them]'. Suetonius (Aug. 98) thus reports the Alexandrian sailors' praise of Augustus: 'it was through him they lived, through him that they sailed the seas, and through him that they enjoyed their liberty and fortunes.' For the invocation of Fortune to protect Augustus, see Horace, Carm. Saec. 29-32. On $\varepsilon \dot{\alpha} \gamma \gamma \varepsilon \dot{\lambda} \lambda \iota v$ and the Caesar cult, P. Stuhlmacher, Das paulinische Evangelium I: Vorgeschichte (Göttingen: Vandenhoeck, 1968) 197-203. 


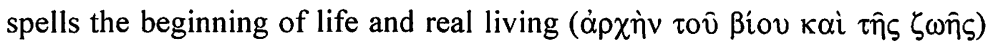
and marks the end and boundary of any regret that they had themselves been born. ${ }^{23}$

As we have seen, the imperial propaganda laid heavy emphasis on the pre-eminent merit of Augustus as benefactor. ${ }^{24}$ Roman writers such as Horace, Virgil, and Velleius Paterculus underline the fact that he had established peace, inaugurated an era of unparalleled beneficence, and secured hope for the future. ${ }^{25} \mathrm{We}$ also hear of Augustus' clemency towards his enemies in the Res Gestae. ${ }^{26}$ These motifs may well have resonated within the minds of Paul's auditors as they heard about Christ's reign of grace. The merit of Christ-seen in his righteous act of obedience to the Father (Rom. 5:18b, 19b) - has secured peace

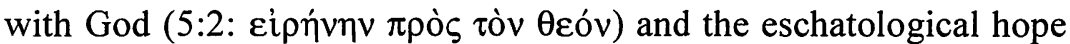
of glory for his beneficiaries (5:2: '̇ं $\left.\pi^{\prime} \dot{\varepsilon} \lambda \pi \hat{i} \delta \imath \tau \hat{\eta} \varsigma \delta \delta^{\prime} \xi \eta \varsigma\right) .{ }^{27}$ However,

23 Ehrenberg and Jones, Documents, §98a (ll. 4-11).

24 The inscription on the golden shield placed in the Curia Julia recognised

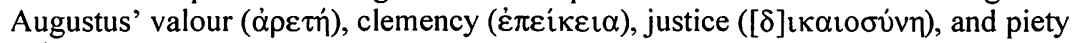

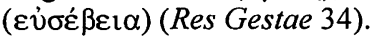

${ }^{25}$ For the imperial ideology of peace, see Augustus, Res Gestae 12 (E[ip]ท́vms

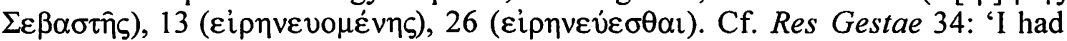
extinguished the flames of civil war.' Similarly, Horace (Carm., 3.14.14-16; cf. $1.2 ; 1.12 .49-60 ; 4.2 .41-52 ; 4.15 .17-20)$ : 'Neither civil strife nor death by violence will I fear, while Caesar holds the earth.' Additionally, Virgil (G., 1.498-514; 2.170-72), Seneca (Apocol. 10), Philo (Leg. 143-44, 147), and Velleius Paterculus (2.89.1-6; 2.126.3-4). Note the more critical stance of Epictetus (Arr., Epict. Diss., 3.13.9-11) who contrasts the peace offered by the Caesars with that of the philosophers.

On the role of benefactors in restoring peace, see Danker, Benefactor, 398-99. On hope in imperial propaganda, see M.E. Clark, 'Images and Concepts of Hope in the Imperial Cult', H.K. Richards (ed.), Society of Biblical Literature 1982 Seminar Papers (Atlanta: Scholars Press, 1982), 39-43. For the benefactions of Augustus, see Res Gestae 15-24. Augustus, in imitation of the honorific inscriptions of Republican nobiles (e.g. CIL I. 2), promotes an eschatological aura around his acts of beneficence and deliverance: 'I was the first and only one (primus et [s]olus omnium) to do this' (ibid., 16). On this feature of Augustus' Res Gestae, see P. Veyne, Bread and Circuses: Historical Sociology and Political Pluralism (London: Allen Lane/Penguin, 1990) 258. Again, as commissioner of the grain supply, Augustus speaks of his generosity in pressing times: 'I freed the entire people, at my own expense, from the fear and danger in which they were' (Res Gestae 5).

26 Augustus, Res Gestae 3 (cf. 34: غ̇ $\pi \varepsilon i \kappa \varepsilon \iota \alpha$ ): 'when victorious I spared all citizens who sued for pardon.'

27 Note the widespread peace and hope terminology in Romans. eipnivn: Rom. $1: 7 ; 2: 10 ; 8: 6 ; 10: 15 ; 14: 17,19 ; 15: 13,33 ; 16: 20$. è $\lambda \pi i \varsigma: 5: 4-5 ; 8: 20 ; 12: 12 ; 15: 4$, 13. $\dot{\varepsilon} \lambda \pi i \zeta \varepsilon \imath v: 8: 24-25$. In relation to Paul's glory terminology (Rom. 5:2), Horace (Carm., 3.25.4-5) speaks of 'peerless Caesar's immortal glory (aeternum decus)'.

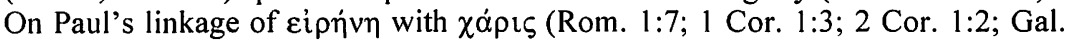
1:3; Eph. 1:2; Col. 1:2; 1 Thes. 1:1; 2 Thes. 1:2; Phlm. 3; 1 Tim. 1:2; 2 Tim. 1:2; 
whereas Augustus had responded with clemency to those who were politically astute enough to sue for peace after the battle of Actium (31 BC), Christ took the initiative and reconciled those who were at the time God's enemies through an act of acquittal (Rom. 5:6a, 8b, 10a, 19b).

The imperial propaganda also portrays Augustus as an eschatological figure. ${ }^{28}$ His principate represents the culmination ( $\tau$ ò $\tau \varepsilon \lambda \eta \dot{ } \tau_{\tau} \tau \tau$ ov) of Providence in the universal history of mankind. The superiority of Augustus as world-benefactor for all time is reinforced by the language of excess $(\dot{v} \pi \varepsilon \rho \beta \dot{\alpha} \lambda \lambda \varepsilon \imath v ; \dot{v} \pi \varepsilon \rho \beta 0 \lambda \hat{\eta}) .{ }^{29}$ Expressions similar to Paul's language of abundance ( $\pi \varepsilon \rho \imath \sigma \sigma \varepsilon v i \varepsilon ı v$ and cognates) also feature in the Priene inscription: the cities of Asia are encouraged to celebrate the birthday of Augustus 'in an even more extraordinary manner ( $\pi \varepsilon \rho \iota \sigma \sigma o ́ \tau \varepsilon \rho \circ v),{ }^{30}$ In similar vein to the documents above, Paul highlights the fact that Christ died for the ungodly 'at the right

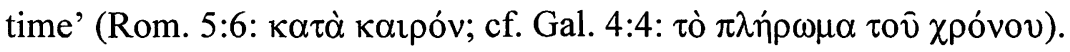
In the context, Kaıpó $\varsigma$ specifies 'the culminating, eschatological time

Tit. 1:4), see J.M. Lieu, "Grace to You and Peace": The Apostolic Greeting', BJRL 68 (1985) 161-78.

28 In Augustan propaganda the battle of Actium acquired a special eschatological significance (Virgil, Aen., 8.675-81; Horace, Epod., 9; cf. Res Gestae 25). According to Virgil (Ecl., 4.1-62), a golden age had been ushered in by Augustus. On the latter, see I.S. Ryberg, 'Virgil's Golden Age', TAPhA 89 (1958) 112-31. The portent of Caesar's comet (Horace, Carm., 1.12.46-48; Virgil, Ecl., 9.46-50; cf. Suetonius, Iul., 88) heralded the eschatological fruitfulness of the Augustan era and its enduring brightness.

29 The language of excess ( $\dot{\pi} \varepsilon \rho \beta \alpha \dot{\alpha} \lambda \lambda \varepsilon \imath v)$ typified benefactors in honorific inscriptions. Benefactors 'excelled' in a range of virtues: e.g. good will ( $\varepsilon$ vैvor $\alpha$ :

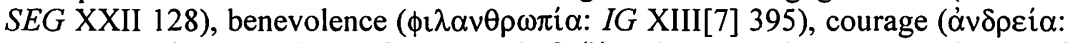
IK Prusa Olymp. 2), love of glory ( $\phi \mathrm{i} \lambda \mathrm{o \delta o} \mathrm{\xi i}_{\mathrm{i} \alpha}$ : Caria. Aphro. 270) and love of honour ( $\phi \imath \lambda \mathrm{o \tau \iota \mu i \alpha :} \mathrm{Bosch.} \mathrm{108,} \mathrm{131),} \mathrm{greatness} \mathrm{of} \mathrm{mind} \mathrm{(} \mu \varepsilon \gamma \alpha \lambda \circ \phi \rho \circ \sigma u ́ v \eta: ~ T A M$

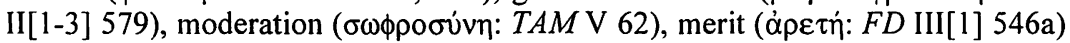

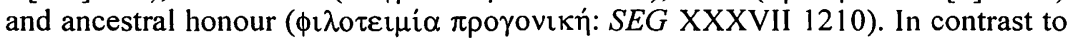
the honorific inscriptions, Paul usually reserves the language of excess ( glory (2 Cor. $3: 10,17)$, power (2 Cor. 4:7; Eph. 1:19), revelation (2 Cor. 12:7) and love (Eph. 3:19). Where Paul employs $v \pi \varepsilon \rho \beta 0 \lambda \eta \dot{\eta}$ in ethical contexts, it refers to the excess of $\sin$ (Rom. 7:13; Gal. 1:13) or, more positively, the excellence of love (1 Cor. 12:31).

30 Ehrenberg and Jones, Documents, §98a (l. 23). Examples of the inscriptional language of abundance are easily multiplied. In honour of Tiberius Caesar, the Ephesians dedicate two stoa 'from the superfluous money ( $\dot{\varepsilon} \kappa \tau \hat{\omega} v \pi \varepsilon \rho 1 \sigma \sigma \hat{\omega} v$ $\chi \rho \eta \mu \alpha \tau \omega \nu)$ of the games of Augustus Caesar' (I. Ephesos 3420). See also I.

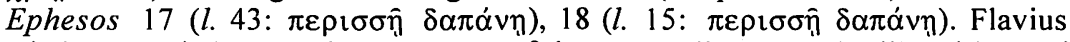
Diadumenos is honoured 'on account of the extraordinary good-will and love of honour ( (I. Tralles 81: AD 217). 
of God's intervention in Christ'. ${ }^{31}$ Later, Paul would identify Jesus as the culmination of the Jewish quest for righteousness by law (Rom.

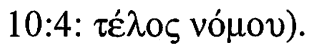

In addition, the Pauline language of abundance points to the supplanting of the Adamic reign of sin and death by Christ's reign of grace and eternal life. ${ }^{32}$ Thus, by the time of Paul, Roman auditors were confronted with two competing eschatological hopes. The imperial version-if Suetonius (Aug. 28.2) has accurately rendered an edict of Augustus-looked beyond the grave to the continuing stability of the res publica: 'I...bear with me the hope when I die that the foundations which I have laid for the State will remain unshaken. ${ }^{33}$ Alternatively, Paul proclaimed the defeat of death itself (Rom. 5:21; 8:38-39; cf. 1 Cor. 15:20-28, 51-57).

Finally, the imperial propaganda ascribed a cosmic status to Augustus. The reason was obvious to all. He had brought about a decisive reversal of the social disintegration unleashed by the triumvirs (and, indeed, Marius and Sulla before them), as they and their factions struggled for political ascendancy (59-31 BC). When Roman civilisation had tottered on the precipice, Augustus offered a new beginning ( $\dot{\alpha} \rho \chi \eta \dot{)})$ that would bring real life (ßíos; $\zeta \omega \eta \dot{)}$ and an end to all regret. The poet Horace $(65-8 \mathrm{BC})$ affords us insight into the profound sense of relief that Augustus brought to a generation wearied by war-guilt and the snubbing of traditional Roman values. ${ }^{34}$ Horace's idyllic description of the fertility of the Augustan age is replete with the motifs of redemption and the restoration of the mos maiorum:

[The] country yearns for Caesar. For when he is here, the ox in safety roams the pastures; Ceres and benign Prosperity make rich the crops; safe are the seas over which our sailors course; Faith shrinks from blame; polluted by no stain, the home is pure; custom and law have stamped out the taint of sin;

31 Moo, Romans, 307.

32 In addition to Theobald (Die überströmende Gnade, passim), note the comment of W. Sanday and A.C. Headlam, (A Critical and Exegetical Commentary on the Epistle to the Romans [Edinburgh: T. \& T. Clark, 1902] 133) concerning Rom.

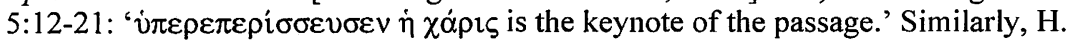
Schlier (Der Römerbrief [Freiburg: Herder, 1977] 172): 'Wir werden auf die Überfülle, den Überfluß, man könnte sagen: dem Exzeß der Gnade aufmerksam gemacht.'

33 See Stauffer, Christ and the Caesars, 109-110.

34 According to Horace, atonement for Roman guilt-rendered necessary because 'citizen whetted against citizen the sword' (Carm., 1.2)-was more than satisfied by the deliverance that Augustus had brought. 
mothers win praise because of children like unto their sires; while Vengeance follows close on guilt. 35

Furthermore, in the Carmen Saeculare, Horace depicts Augustus as a new Aeneas, who according to later legend was Rome's founder (Carm. Saec. 37-48). An eschatological figure, Augustus establishes a worldwide reign of fruitfulness (Carm. Saec. 29-32) and peace (4956) that embodies the quintessential Roman values (57-60). ${ }^{36}$

The inscriptions replicate this blend of eschatological and cosmological expectation regarding Augustus. The island of Phylae, located at the first waterfall of the Nile, honoured Augustus' conquest of Egypt some twenty-three years after the event and accorded him a quasi mythological status:

The emperor, ruler of oceans and continents, the divine father among men, who bears the same name as his heavenly father-Liberator, the marvellous star of the Greek world, shining with the brilliance of the great heavenly Saviour. 37

Even Philo, the Jewish philosopher of Alexandria, ascribes to Augustus the role of social and cosmic healer:

The whole human race exhausted by mutual slaughter was on the verge of utter destruction had it not been for one man and leader, Augustus, whom men fitly call the averter of evil. This is the Caesar who calmed the torrential storms on every side, who healed pestilences common to Greeks and barbarians, pestilences which descending from the south and the east

35 Horace, Carm., 4.5.16-24 (LCL; tr. C.E. Bennett); cf. 4.15. See also Virgil, G., 1.24-42. Generally, see W. Deonna, 'La légende d'Octave-Auguste: dieu, sauveur et maitre du monde', RHR 83 (1921) 32-58, 163-95; RHR 84 (1921) 77-107; A. Wallace-Hadrill, 'The Golden Age and Sin in Augustan Ideology', $P \& P 95$ (1982) 19-36. For Augustus' stated faithfulness to the mos maiorum, see Res Gestae 5, 8.

36 See Georgi's excellent discussion, 'Prophet', 115-17. The Ara Pacis (Altar of Peace), erected in the Campus Martius between 13 and $9 \mathrm{BC}$ to celebrate Augustus' return from Gaul, includes a representation of Aeneas arriving in Italy. 37 Cited in Stauffer, Christ and the Caesars, 99. Note, too, the cosmological dimension of I. Perge 381: "[This monument is dedicated to] Imperator Caesar Augustus, Son of a God, Guardian of all the earth and sea.' Cf. Rev. 10:6; 14:7. A late first-century BC prophecy in honour of Augustus' victory at Actium (or is it possibly a reference to Caesar's triumph at Pharsalus?) is I. Hadrianoi 24, which reads: 'I, Gauros, have received the trustworthy words of prophets and have inscribed the victory of Caesar and the other [credible words] of [the] gods, from whom with prayer I have all things from beginning to end and, giving back gifts agreeably, I am proud. Gauros, son of Asklepiades, Toreanos, [has erected] the statue from his own [money].' According to Paul, the gospel of the risen Son of God in power was 'promised beforehand through (God's) prophets in the Holy Scriptures' (Rom. 1:2; cf. 16:25-26). Georgi ('Prophet', 87) argues that Rom. 1:34 is 'an alternative to the social utopia of Caesarism'. 
coursed to the west and north sowing seeds of calamity over the places and waters which lay between them. ${ }^{38}$

Paul's portrayal of Christ as the eschatological figure of world and cosmic history would have registered with Romans imbued with the Augustan eschatology (and who may well have been alienated by imperial successors such as Caligula and Nero). ${ }^{39}$ According to Paul, humanity is held hostage to sin and death through the disobedience of Adam its founder (Rom. 5:12-14). The entire creation, which was subjected by God to futility at Eden (Rom. 8:22; cf. 15:30; Gn. 3:1719), currently groans (Rom. 8:23) and awaits the culmination of the redemption hope, equally for itself and for Christians at the eschaton (8:20b-21, 23b). But, as the first-born from the dead (Rom. 8:29; cf. Col. 1:18), Christ is the beginning of a new humanity (Col. 1:18:

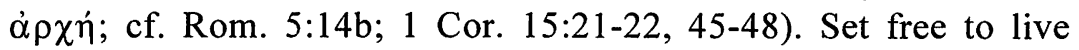
without the crippling legacy of its founder $(\zeta \omega \eta$ : Rom. 5:17b, 18b,

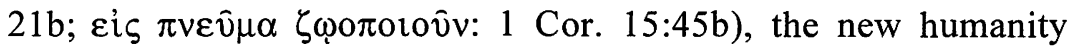
experiences through Christ a restoration of the original righteousness of Eden $(5: 16 \mathrm{~b}, 17 \mathrm{~b}, 19 \mathrm{~b}, 21 \mathrm{~b}){ }^{40}$ In contrast to the Priene inscription of Augustus, an eschatological reserve characterises Paul's good news ( $\varepsilon \dot{v} \alpha \gamma \gamma \varepsilon \dot{\lambda} \lambda$ lov). With the advent of Augustus all regret is banished; conversely, however, the believer waits in hope for the eschatological glory (Rom. 5:2; 8:20, 24-25). But, given the inevitability of suffering (Rom. 5:3-5; 8:18, 35-36), worldly and cosmic powers cannot separate the believer from the love of Christ (8:35-39), precisely because his death is the guarantee of God's continued beneficence towards his people (8:32: $\chi \alpha \rho i ́ \sigma \varepsilon \tau \alpha \imath)$.

\section{Conclusion}

Although Paul formulates his understanding of the eschatological fullness of grace within a Jewish matrix, his presentation of Christ's work in Romans 5 and Romans 8 might have reminded listeners of

38 Philo, Leg. 144-45. For a sensitive discussion of Philo's eulogy of Augustus, see D.L. Tiede, Jesus and the Future (Cambridge: CUP, 1990) 25-26.

39 Georgi ('Prophet', 99) observes: 'Romans was written at the very beginning of Nero's rule, when propaganda based on...prophetic and theological speculations, with intense eschatological expectations, enjoyed immense popularity.' T.M. Coleman ('Binding Obligations in Romans 13:7: A Semantic Field and Social Context', TynB 48 [1997] 325) argues that Romans was written 'during a time of increasing dissatisfaction over the burden of taxation in the Neronian Principate'.

40 Righteousness was the characteristic of Eden and its inhabitants (1 En. 32:3; $60: 8,23 ; 70: 3 ; 77: 3)$. 
the eschatological motifs of Augustan beneficence, along with the implicit hint for contemporary hearers that Christ's generosity surpassed even that of the Caesars. ${ }^{41}$

Was this a deliberate strategy on Paul's part or not? The question is difficult to answer definitively. I suspect it was. The language of

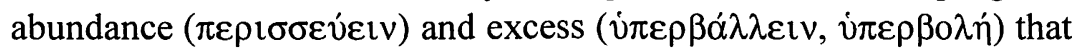
regularly accompanies Paul's language of grace is also found on the Augustan inscriptions of the first century. ${ }^{42}$ But in the wider corpus of honorific inscriptions, it is the language of commensurability ( $\alpha$ k

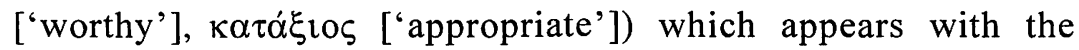
language of grace. ${ }^{43}$ The reason for this is clear. In the Graeco-Roman reciprocity system, the recipient of favours had to return honours and gifts that were 'worthy' of the original benefactions. ${ }^{44}$ But for Paul and for Augustus, grace simply overflowed.

41 Danker (Benefactor, 347) writes: 'Such grace was beyond a Caesar Augustus.'

42 D. Zeller (Charis bei Philon und Paulus [Stuttgart: Verlag Katholisches Bibelwerk GmbH, 1990] 135 n. 199) cites two cases of Philo employing $\chi \alpha \dot{\alpha} \rho \varsigma$ with $\pi \varepsilon \rho \imath \sigma \sigma \varepsilon v i \varepsilon \imath v$ (Leg. All. 1.34; 3.163), correctly observing that Paul's use was not unique. But, as we have seen, $\pi \varepsilon \rho \imath \sigma \sigma \varepsilon v i \varepsilon \imath v$ (and cognates) was part of benefaction parlance (nn. 30-31 above). J. Wobbe (Der Charis-Gedanke bei Paulus: Ein Beitrag zur neutestamentlichen Theologie [Münster: (no publisher cited), 1932] 41) notes how Paul employs a range of abundance terminology

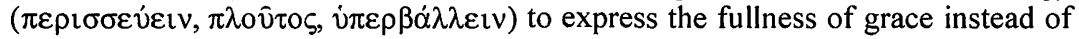
resorting to the plural $\chi \alpha \dot{\rho} \rho \imath \varepsilon \varsigma$.

43 See my book, Paul's Language of Grace ( $\chi \alpha \dot{\alpha} \rho \varsigma)$ in its Graeco-Roman Context (WUNT: Tübingen: Mohr Siebeck, forthcoming) §2.4; 7.3.2.1.

$44 \kappa \alpha \tau \dot{\alpha} \xi 10 \varsigma$ and $\alpha \xi_{10 \zeta}$ regularly appear with $\left.\chi \alpha \dot{\alpha}\right\lrcorner \varsigma$ in the 'manifesto clause' of honorific inscriptions. The 'manifesto clause'-introduced by ö $\pi \omega \varsigma$ or ï $\alpha$ ('in order that') along with $\phi \alpha i v \eta \tau \alpha \mathrm{l}$ ('it may be manifest') and the participle—sets out the rationale for honouring the benefactor. The reasons for erecting the public decree are mutually advantageous to both the benefactor and his beneficiary. Consequently honorific rituals act as an incentive to future benefactors. One example will suffice. The city of Akraiphiae (C. Michel, Recueil d'inscriptions grecques [Brussels, 1900; reprint, Hildesheim: G. Olms, 1976] §235 [146 BC]) praises the people of Larissa for sending them three exemplary judges and stipulates that the decree be set up as a votive gift 'in order that (ö $\pi \omega \varsigma$ ) it may be manifest ( $\phi \alpha i v \eta \tau \alpha)$ ) to all that the Akraiphiae are able to return appropriate

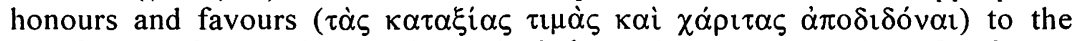
benefactors of themselves, and that the judges who are present thereafter for us, observing the gratitude of the Akraiphaia, may compete $(\dot{\alpha} \mu \imath \lambda \lambda \hat{\omega} v \tau \alpha \mathrm{l})$ for (a reputation of) nobleness'. For further discussion, see my Paul's Language of Grace, §7.3.1.1. 